\title{
Realizing multiculturalism and social integration in Banuroja community
}

\author{
Wahyudin Noe ${ }^{1}$, Novia Wahyu Wardhani ${ }^{2}$, Sitirahia Hi Umar ${ }^{3}$, Rasid Yunus ${ }^{4}$ \\ 1,3 Pancasila and Civic Education Study Program, Universitas Khairun, Ternate, Indonesia \\ ${ }^{2}$ Pancasila and Civic Education Study Program, Universitas Negeri Semarang, Semarang. Indonesia \\ ${ }^{4}$ Pancasila and Civic Education Study Program, Universitas Negeri Gorontalo. Gorontalo, Indonesia
}

\begin{abstract}
There have been many studies concerning Banuroja; however, there is always something novelty in creating a role model for village-based character education where the aim is to create a multicultural society into a multicultural community. This study examines community activities related to the national character values that embody multiculturalism and social integration in the Banuroja community. The method was qualitative with an ethnographic approach. Data were obtained from observations, interviews, and documentation carried out during 2019-2020. The validity of the data used triangulation, member checks, prolonged time, and peer debriefing. While the data analysis technique used ethnographic data analysis, namely describing, analyzing, and interpreting. The result shows that the realization of multiculturalism and social integration in the Banuroja community is carried out using three ways of assimilation, tolerance in beliefs/religions, appreciating other ethnic/religious activities by attending, and mutual cooperation. Guidance is also carried out through national and religious activities in the community, advice from parents in the family, and civic education in the schools, exemplary by community leaders, including ethnic, religious, and youth leaders.
\end{abstract} Article History: Submitted

Keywords:

Banuroja; multiculturalism; social integration

Cite in APA ${ }^{7 \text { th }}$ :

Noe, W., Wardhani, N., Umar, S., \& Yunus, R. (2021). Realizing multiculturalism and social integration in Banuroja community. Jurnal Civics: Media Kajian Kewarganegaraan, 18(1), 82-96. doi:https://doi.org/10.21831/jc.v18i1.37983

\section{Introduction}

Indonesia has a large community diversity related to ethnicity, race, religion, and class. These differences are based on habits, teachings, customs, and culture or norms and morals, which divert the nation in that point. Diversity conflict, however, can occur at the same time. Some divert communities in terms of culture and religion live harmonically (Syafar, 2019; K \& Mahyuddin, 2019). While Ernas (2018) and Jubba (2019), found these diversities can also create the primordial attitudes and ethnocentrism that are dangerous for peace embodiment. To shape a society that upholds multiculturalism and social integration requires understanding and awareness in applying national character values to the life of society, nation, and state.

We can find national character values in the four basic foundations of the Indonesian state, the state ideology, namely Pancasila, the 1945 Constitution of the Republic of Indonesia, Sesanti Bhineka Tunggal Ika, and the Unitary State of the Republic of Indonesia (NKRI). There are five main values, namely divinity, humanity, unity, democracy, and social justice. These are derived from ethnicity, culture, and religion in Indonesia

Empirically, the application of national character values has not been implemented optimally. It can be seen from some people who still show behavior that is not following the values 
of the character of the nation, such as provoking and playing against the community, intolerance accompanied by the violence against other groups/classes, increasing the ethnic primordialism, and discrimination (Noe et al., 2018). Regional conflicts also often occur along with a lack of understanding of diversity or multiculturalism (Rifai, 2017). Such behavior can certainly trigger conflict in the community, and even if it is not controlled, it has the potential to become more expansive and expand into social conflicts; as happened in the Maluku (Ambon) area in 2002, in Sampang, East Java in 2011, in Aceh Singkil in 2015, in Papua which more precisely in Tolikara area in 2015 and Wamena in 2019 which are still around. Of course, this condition cannot be ignored because it can lead to the disintegration of the nation

Social conflicts due to multicultural problems may recur if people do not understand and awareness of the importance of national character value. The low ability to apply the nation's character's values can be caused by the fact that people only interpret it as limited as knowledge, not yet internalized into each of them. The concept of value education is theoretically a fundamental principle, namely the substance of value is not merely captured and taught but further, the values are digested in the sense of being captured, internalized, and standardized as an inherent part of a person's personal quality through the learning process (Fajar \& Wati, 2012).

The process of understanding and learning about the values collides with the interpreting values that are abstract and multiple interpretations (Wardhani, 2020). Therefore, it is not only necessary to be internalized but also transformed. The transformation of the national character values can be carried out by fostering and strengthening the three education centers, namely the family, school, and community environment. This process is carried out to prevent conflicts due to the differences and strengthen multiculturalism and social integration in society.

The society in Indonesia, which has diversity, requires a transformation of the nation's character's values to achieve social integration. Multiculturalism is a term used to describe a person's view of the diversity of life in the world, or cultural policies that emphasize the acceptance of diversity and the various kinds of (multicultural) culture that exist in community life regarding the values, systems, culture, habits, and politics that they trust. Besides, there is a desire to study and understand the diversity of cultures by being open and happy to increase the knowledge and experience of cultural diversity and strengthen each culture's interrelationship. The primary reference for realizing a multicultural Indonesian society is multiculturalism, which is an ideology that recognizes and glorifies the differences inequality, both individually and culturally (Fay, 1996; Watson, 2000; Suparlan, 2002). Meanwhile, social integration is more of an effort to unite wherein a multicultural society; there is a need for unity which recognizes that they are the Banuroja community and the Indonesian people.

Gorontalo, to be precise, in Banuroja village, Randangan district, Pohuwato Regency, is called by several researchers as an excellent example of the application of multiculturalism in Gorontalo (Noe, et al., 2018; Walidaeni, 2018; Faisal, 2019; Zaenuri \& Pratama, 2019). Banuroja Village's people have carried out the national character values' internalization to realize multiculturalism and social integration. In the preliminary observations made in January 2019, this village is in Randangan Subdistrict, Pohuwato Regency, which is about $250 \mathrm{~km}$ from the capital city of Gorontalo Province. The Banuroja community is also inhabited by various ethnicities, consisting of Balinese, Sasak, Javanese, Minahasa, Batak, Bugis, and Gorontalo, and also consists of four different religions, namely Hinduism, Islam, Protestant Christianity, and Catholicism. The activities in preserving and developing the character values as a good character in the people's daily lives have been seen. For example, they respected the guests from outside who come, respecting each other, respecting other religions' worship activities, mingling with each other without distinguishing social identities, and mutually helping the people who need help. The people of 
Banuroja have succeeded in demonstrating that harmony is not just passive co-existence; it is not artificial harmony. In the context of Banuroja, living in diversity is actualized by active co-existence in close friendship, dissolving in the features of each rite without criticizing the other rites (Faisal, 2019). These attitudes and behaviors have come a long way since the formation of Banuroja society in the 1980s. As a result, this village received the safest village title in Randangan district from the Pohuwato regional government and Pancasila village from the State University of Gorontalo. This predicate is an appreciation to the Banuroja community for their success in maintaining peace in their village. In Morgenthau (1963) terms, "certain qualities of intellect and character occur more frequently and are more highly valued in one nation than in another." Therefore, the people of Banuroja have a high commitment to implementing the values of national character to foster a family spirit in the community based on "Bhineka Tunggal Ika" (different but one), which is the motto of the nation's life. The social capital that the Banuroja community has in strengthening multiculturalism and social integration can be used as a role model for character development in other areas, especially heterogeneous societies.

\section{Method}

This research was conducted in Banuroja Village, Randangan District, Pohuwato Regency, Gorontalo Province in 2019-2020. It was a qualitative study using an ethnographic approach. This research is also related to the curiosity in answering the questions about how the dynamics of multicultural values in the development of social integration and how the process of internalizing the values to society shapes the character of the nation. Ethnographic approach was used to photograph the daily lives of the Banuroja people so that they get a clear picture of the description of the answers to the problems to be discussed. Ethnography was used because the Banuroja community has a uniqueness not shared by other communities, especially in building the character towards the society that upholds multiculturalism and social integration.

The data were collected through observation, interviews, and documentation. The observations were conducted from March 2019 - March 2020 in Banuroja Village regarding the community activities in the places of worship, village offices, schools, and public places, such as when their children mingle playing in the field. The research subjects consisted of 16 people such as the religious leaders, ethnic figures, village government, youth leaders, local governments, and Citizenship Education academics. The selection of research subjects such as religious leaders, ethnic figures, and youth leaders was based on obtaining broad and in-depth information regarding implementing national character values in the Banuroja community from the past to the present. The research subjects from the local government and village government were then selected based on obtaining information about the government's role in strengthening the value of the nation's character in the Banuroja community. Meanwhile, the research subjects from civic education academics should strengthen the research studies from the theoretical and empirical aspects of national character values in a multicultural society. Besides, the documentation was obtained from the village archives and some previous research.

To strengthen the research data's trustworthiness, Creswell (2015) data validity checks were used, which consisted of triangulation, member checks, a relatively long time (prolonged time), and peer debriefing. The triangulation is carried out; therefore, the data obtained can be checked for correctness to several parties to avoid the researcher's subjectivity. The member checking is intended so that the informants know the research results in the hope that there will be no 
rejection and support the results of the research. The relatively long time is intended for researchers to spend more time at the research location to obtain valid data information related to the people's characteristics and the socio-cultural conditions of the local community. Meanwhile, fellow researchers' questions and answers were conducted to obtain additional information that could strengthen this research.

The collected data were analyzed using ethnographic data analysis, namely description, analysis, and interpretation (Creswell, 2015). The purpose of a data description is data and information obtained from the observations, interviews, documentation, and audio-visuals that are depicted as objectively as they are based on the facts of events found in the field. After the researcher has described the data, it is then analyzed, meaning that the researcher chooses the data to suit the research objectives. The final step is interpreting, where the researcher concludes the data and information that has been previously analyzed and combines them with relevant theories in interpreting the research

\section{Result and Discussion}

Banuroja Village is one of the villages in Randangan District, Pohuwato Regency, Gorontalo Province. This village is unique because its people are a mix of various cultures, ethnicities, and religions. This diversity is motivated by the origins of the Banuroja people, who are extransmigrants from several regions. These areas are DKI Jakarta, West Java, East Java, Bali, West Nusa Tenggara, and North Sulawesi. The total population of Banuroja Village is around 1151 people, consisting of 473 Balinese ethnicity, 293 Javanese ethnicities, 300 Sasak ethnicity, 37 Minahasa ethnicity, 29 Gorontalo ethnicity, 8 Bugis ethnicity, and the rest Batak ethnicity, 11 inhabitants. Meanwhile, according to the religious adherents, there are 630 Muslims, 473 Hindus, 41 Protestant Christians, and 7 Christians (Banuroja village document 2020).

The name of Banuroja Village itself means $B a=B a l i, N u=N u s a$ Tenggara, $R o=$ Gorontalo, and Ja = Java. The naming of the village is an agreement between representatives of ethnic and religious figures by taking an acronym (abbreviation) from the area of origin of the community. The ethnic groups who inhabit the village consist of; Balinese, Sasak, Minahasa, Gorontalo, Javanese, Buginese, and Batak ethnic groups. There are different religions, including Islam, Christianity, and Hinduism.

Starting from this village's existence until now, the people of Banuroja have implemented the values of the nation's character well so that they can strengthen the social integration in their communities. In general, several things determine this success, namely: 1) Strengthening multiculturalism and social integration by getting used to implementing the values of national character in the society, families, and schools; 2) Fostering the national character values through activities in the community, in the family, and at school; 3) Exemplary of community leaders as the model for building national character. More details will be described below.

\section{Habituation}

Habituation is the first strategy undertaken by the Banuroja community in building the character of their community in creating multiculturalism and social integration. In the internalizing character values for children, habituation that takes place every day is an education received by children and inspires the character development and future potential (Asrori, 2019). It also requires unification or integration efforts first to get to know each other. Knowing is the individual and the initial identity that they carry, such as their values, religion, culture, and habits. The unification at the beginning of habituation is carried out through community activities. The national character values possessed by the Banuroja community, which have been accustomed to 
exist and develop in supporting multiculturalism and national integration, include religious values, tolerance, peace-loving, social care, the spirit of nationality or unity, and responsibility. For more details, the author will describe it as follows:

One of the values preserved by the Banuroja community is religious values. It is very attached to the personality of the community without degrading other religions. They show their respective religious identities, such as worship activities and religious cadres held regularly in their daily lives. For example, Muslims can be seen from worship rituals (prayer) and recitation activities in the mosques. Hindus are seen in prayer and cadre activities at temples, while Christians are seen from weekly worship at the Church. For them, this religious difference can strengthen the religious / faith values because it shows awareness in the religion. Like the Muslim community where they apply and believe that Allah SWT created the different people to get to know each other. Likewise, Christians believe that all of His creations must be loved. Hindus love each other so much as a form of maintaining the world's existence; this shows strong religious values. It also shows that understanding and awareness of multiculturalism can be said to be very good, as stated by Kowalczyk and Popkewitz (2005) that "multiculturalism articulated as 'the character' who can bestow a greater, more inclusive society", where multiculturalism is articulated as a 'character' which can provide a greater and more inclusive society.

Then, other religious values are shown by positioning the religious figures as highly respected in society. They always support and obey every edict or recommendation of religious leaders in the form of good attitudes and behavior. That obedience further strengthens the attitude of tolerance. It minimizes the potential of conflict between the religious communities when faced with the various problems in the society, whether they come from their own internal or external parties who want to disturb their long-standing harmony. In this case, in line with Ibn Khaldun's concept of social control or supervision, the need to practice religious values (religion) is applied in personal life, family, group, organization, society, and the state. By practicing religious values well, it is claimed that will prevent humans from evil deeds and behavior, deviant behavior (Muhammad, 2015).

Apart from the religious values, there is also a value of tolerance which is one of the nation's character's character that the Banuroja community has practiced. The tolerance is accustomed and strengthened because this nation has the local wisdom that teaches the beauty of tolerance between the tribes, religions, groups, and regions to achieve harmony and balance in the life of society, nation, and state (Wardhani \& Narimo, 2018). The value has taken root in every citizen, which can be seen from the attitudes and behavior that mutual respect for the differences in ethnicity, religion, and class. The attitude of tolerance in the religion can be seen when the adherents of religions respect each other's worship practices to walk safely, calmly, and comfortably in the worship. One of the values of tolerance comes from religion. It has provided the adherents with the ideas (Sutiyono, 2011). It also forms the concepts about the order of all existence to move the feelings of its adherents to do something behavior (Mangunsong \& Fitria, 2019). The tolerance also comes from four national consensuses, namely Pancasila, the 1945 Constitution of the Republic of Indonesia, Unity in Diversity, and the Republic of Indonesia. The concepts represent the importance of tolerance. The behavior can be seen at the time of worship using the musical instruments and loudspeakers such as the call to prayer (azan), recitation, 
Christmas, which can be heard reaching the congregation of other people considering the location of the house of worship, which is close to each other. It was said by I Made Suardana as the Head of Banuroja Village that:

"Religious people in this village respect each other. For example, when there is a religious event that uses musical instruments or speakers, no one will question it and do not feel disturbed. So, if there is someone who still disputes the speaker as the main cause of conflict, it does not apply here because there is mutual understanding".

For them, this is not a problem because they have developed a mutual understanding. The attitude arises from their understanding and awareness to build mutual tolerance towards the existing differences and the importance of building a peaceful civilization. Whereas, in other areas where people of different religions, this condition can be a problem. In Azra's point of view (2007), multiculturalism is "a world view that can be translated into various cultural policies that emphasize the acceptance of religious, plurality and multicultural realities that exist in the people's life." The attitude is necessary for multicultural societies to maintain social integration.

Other forms of tolerance appreciate every religious ceremonial activity and other ethnic cultures, such as attending invitations to celebrate other religions' holidays by giving mutual congratulations and support. This attitude shows that Banuroja residents have a moderate understanding and are open to existing differences. They do not want it because the excessive fanaticism (extreme) towards their beliefs can destroy the harmony of life that has been nurtured and built for a long time. Meanwhile, a form of appreciation for other ethnic cultures is shown by attending and watching the performances of other ethnic cultures, such as local dances at official events. The dance performance is intended to entertain the other ethnic groups who witness it and add references to the cultural differences with their respective peculiarities. According to Fromm (2002), it is called "relatedness." The attitude of tolerance has strengthened the harmony in the Banuroja community.

Besides, the Salafiyah Syafi'iyah of Islamic boarding school in Banuroja village also contributes and plays a massive role in accustoming and strengthening the residents' tolerance. The influence even extends to the communities in other areas. This school continuously broadcasts the value of tolerance not only to Muslims, but it is also to non-Muslims. Verkuyten and Yildiz (2007) terms, "religion is an important dimension for developing a positive social identity, and religion is an important factor in social divisions and conflicts in many societies around the world." Thus, Sudarma said that the Unitary State of the Republic of Indonesia (NKRI) has committed that multicultural and multi-religious primary assets must be packaged with an attitude of tolerance and a spirit of integration (Purna 2016).

The following national character value that is preserved by the Banuroja community is the value of peace-loving. In a multicultural society, good cooperation is needed in maintaining peace. Banuroja people have been done this; although they are diverse in religion and ethnicity, they protect each other. Such an attitude can be seen when there was a provocation from outside parties who carried the extreme intolerant teachings in viewing religious differences in the 2000s originating from conflict areas (Poso), then at that time, the residents responded it quickly and firmly to reject these teachings. Of course, this attitude has been through coordination and consolidation with the religious leaders and the local government. 
They also have a strong awareness of mutual respect to maintain the peace of their village by keeping away the bad behavior that can trigger the community's conflict, such as primordialism, intolerance, and hate speech. For Banuroja people, disputes can occur because of personal problems (personal), not religious or ethnic reasons. Personal problems intended such as sentiment towards other people or groups, or because of the youth delinquency due to the effects of drinking (drunkenness). That in line with the results of research by Verkuyten and Yildiz (2007), Wolsko, et al., (2000), and Kauff et al. (2013) that "while research shows that appreciating the differences between ethnic groups often goes along with more positive outgroup attitudes compared with the perspectives neglecting the differences between groups." Therefore, when there is a problem in the village, it is resolved more quickly through a deliberation process. The problems can also be resolved independently by involving the warring parties, community leaders, and parents and not involving the external parties such as the police. Such a resolution process can reduce the potential for conflict to a greater extent and strengthen social integration. It is in line with the view of Layendecker (1983), social integration is achieved if it meets the conditions that "a society is always integrated due to the growing consensus (agreement) among the majority of community members regarding the fundamental social values." The same thing was said by William F. Ogburn and Meyer Nimkoff (in Coleman, 2008) the conditions for achieving the social integration, namely: "1) the community has succeeded in creating a joint consensus regarding the social norms and values that are preserved and used as guidelines in interacting, and 2) social norms and values have been in effect for a long time and are made consistent and not easily subject to change so that they become standard rules in carrying out the process of social interaction".

The next nation's character value that is no less important is shown by the Banuroja community, namely social care. It is defined as a person's involvement in helping to carry out the various activities in society. As for the Banuroja community's involvement so far, which should be appreciated, such as providing material assistance when the resident is grieving, is hit by a disaster, carries out a wedding celebration, gives birth, or helps the necessities of life for a poor family. The assistance given does not see from which the identity or class the person is, but it is intended solely to ease each other's burdens and strengthen their sense of brotherhood among others.

Moreover, other social concerns can be seen when there are residents who are building or moving their houses. Usually, they come together immediately without being asked by the host. They work together voluntarily until the job is finished. The host feels it is helped by the energy to be lighter, more efficient costs, and relatively faster when compared to using the services of a builder. That has shown the value of their social care, which can strengthen their community's social integration. It can become a driving factor for the formation of social integration as stated by Soekanto (2011), "the increase in social solidarity is influenced by the intensity of group cooperation in the society in facing common events." In Nathan (2015) term, this is one of the basic social facts for a multicultural society: "we are interdependent beings", which means that everyone depends on other people, both directly and indirectly, to achieve their life goals in society.

The other national character value that can strengthen the social integration of the Banuroja community is the value of the spirit of nationality or unity. It can be seen from their character, 
which emphasizes the attitude of nationalism more than their respective ethnicities or religions. One example is being open and accepting of the local community (Gorontalo) to the immigrant community (transmigration). They blend in and become friends without feeling better than the other. Everything is equal and fair in taking a role in social life. Unlike in other areas, social conflicts can occur between the immigrant communities and local communities because there is no mutual respect and appreciation for each other. Besides, their spirit of nationalism is shown by not being fanatical about their understanding and beliefs, such as understanding religious teachings. They always respect each other and prioritize common interests to always live together in ethnic and religious diversity. When there are differences in opinion or views, it is pursued prudently and wisely through a deliberation process to produce a mutual agreement. The method shows the high value of nationalism in their lives, as I Wayan Sukra as a Hindu figure, said, "Banuroja people are very Pancasilaism and have a high spirit of nationalism, always being moderate in deciding the problems." The same thing was stated by K.H Abdul Ghofir Nawawi as a Muslim leader that:

"The people here prioritize the spirit of nationality rather than religion, ethnicity, or class. In Islam, it is known as "Islam Nusantara", which means culture or tradition that is valued with an Islamic spirit. The public has kept the primordial attitude away because it triggers the problem".

The Banuroja community also preserved another national character value that is the value of responsibility. It has been inherent in every citizen. In any activity of the community, it cannot be released from the responsibility. One example, when the residents are involved in terms of village government by holding certain positions, they can be accountable for this mandate as well as possible. Moreover, the positions related to village budget management are obtained, among others, from the government, such as village funds, so that the residents manage them professionally and transparently to maintain the trust of the citizens.

Other responsible attitudes are such as conducting buying and selling transactions within the community. When making transactions such as food, goods, livestock, and others, they trust each other and are not worried or suspicious. There is a principle of responsibility in buying and selling, even an enormous value such as buying and selling livestock. This condition has been developed because every citizen maintains mutual trust and tries to occupy every promise as a sense of responsibility. They trust each other and are not worried or suspicious of each other, as stated by Rony Koyansow as a Christian leader that "in trading, sometimes there are buyers who are lack of money. Usually, the seller allows the goods to be brought home, and then after that, he pays them. There is the principle of responsibility in buying and selling, even with a large value as buying and selling livestock". Responsibility is one of the national character values that can reinforce and strengthen the social integration of the Banuroja community. They maintain the value because if they violate or ignore it, they will be subject to strict sanctions in the form of customary sanctions.

Habituation in its goal of building multiculturalism and social integration can be seen from the unification process in respect of others' religious and cultural habits. It is created because the habituation makes them realize that it is no longer relevant to have views that differentiate between ethnicities, religions, or groups in a multicultural society. Instead, they all come together to create entities that respect each other and unite in diversity. The differences are no longer an obstacle to society's development in the social, economic, and political fields. That is in line with 
what Kymlicka (Whittaker, 2014) states that "We need to rethink the way we view nations in a way that he terms 'post-ethnic, but by doing so he assumes that national identity can be easily bound to the dichotomy between ethnic and civic nationalism. In an increasingly multicultural age, this kind of distinction seems less viable. Instead, we should be looking at how both can continuously merge to create a more plural entity".

\section{Fostering the Character of The Nation Through Activities In The Community, Family, and Schools}

One of the vehicles for the formation of social integration in the multicultural Banuroja community is through guidance. This success is due to fostering the national character values to the community through religious leaders, families, and schools as a preventive effort to strengthen the social integration in the community. The coaching process is as follows:

First, it is instilled the national character values through the national and religious activities in the community. One of the Banuroja community's efforts in strengthening the social integration in society is to provide fostering of national character values to the community through religious and national activities. Such activity serves to instill a value of tolerance and tolerance in the community. In the terms expressed by Jenson (in Kærgård, 2010) it is called social cohesion, namely "thus social cohesion is fostered by conflict management of mobilized differences (or cleavages) of all sorts - cultural, linguistic and economical." It means that fostering is carried out to manage the conflicts from differences/divisions in cultural, linguistic, and economic aspects. With guidance, we can be aware of the emergence of multiculturalism debates because multiculturalism will only lead to divisions in society when it is not adequately guarded. So far, each ethnicity or religion has always provided continuous guidance to be harmonious and peaceful in social life. It is instilled through the activities of Isra Mi'raj, Halal bi Halal, and recitation at the Ta'lim Council for Muslims. For Hindus, there is the name Darmasanti. For Christians, it is instilled in their respective churches through events such as Christmas.

Besides, the fostering of national character values is carried out through formal village meetings and customary forums. When the formal village meeting takes place, the community reminds each other to keep the spirit of kinship amidst the diversity of religions and ethnicities. Likewise, when the customary forums take place, ethnic leaders always remind their members to be tolerant of each other towards the differences to strengthen society's unity. However, the customary forum only applies to ethnic Balinese, as stated by I Wayan Ase, that "in ethnic Balinese, there is a customary forum held every month to exchange the village development views and instill a value of tolerance in the members." These various efforts have had a positive impact on the attitudes and behavior of the Banuroja people for the better. In Budimansyah (2010) terms, "in the community, the efforts are made to ensure that there is a strengthening process of community leaders towards the noble behavior developed into daily activities in their respective communities".

Second, it is instilled the national character values by advising the children in the family environment. Inculcating the national character values can also be carried out in the respective family environment, where the parents have a vital role in fostering the character values to their children in the form of advice to have a good attitude and behave well in the family and the society. In addition to advice, parents also directly provide good examples to be emulated, such as the 
social relationships that parents develop in a harmonious and tolerant society that their children can imitate. Therefore, the establishment of national character values in the family environment is crucial for the formation of social integration, so parents must be equipped to educate the character because it requires intermediaries to form and develop (Wardhani, et al., 2019).

Third, it is instilled the national character values through the learning process in the school environment. Inculcating national character values can also be carried out in the school environment, such as teaching children to have a good attitude and behave well. Banuroja Village has three schools, namely the Public Elementary School of Banuroja (SDN), the Vocational of High School (SMK), and the Salafiyah Syafi'iyah of Islamic Boarding School. Based on the observations at SDN and SMK, the national character values are learned through the Civics Education (Civics) subject. This subject serves to equip the children with knowledge of citizenship so that the hope is that they will be able to show good character in their interactions. In the Salafiyah Syafi'iyah of Islamic boarding school, they are equipped with comparative religious knowledge to strengthen the aqidah and a high sense of nationalism. Through this material, it can shape a moderate personality towards the religious views. So that they can live in harmony with other people while minimizing the fanaticism towards both ethnic and religious identities, as Arjun and Osman (in Yousuf, 2007) said that "education as a means of discouraging extremist elements and promoting integration within a multicultural society, " where education is a means to minimize the extremist elements and encourage the integration in a multicultural society.

Besides, the inculcation of national character values in Banuroja children can be carried out through mingling each other in the social relationships by not seeing each other's differences and respecting others' opinions. When there is a misunderstanding in socializing, it can be resolved peacefully. The mingling of children in playing has become an indication of social integration in society. It can be seen from their interactions when they are playing or doing group assignments in class/at home; they mingle with each other and work together without differentiating from one another. The habituation process is an effort to strengthen the spirit of friendship. In the term Budimansyah (2010), that "fostering student character should not only be carried out in the classroom when the lesson is taking place but must be continued outside the classroom through the character life habituation activities." Fostering through a process of learning and habituation can strengthen Banuroja children's character for the better so that it becomes a social investment in strengthening social integration.

\section{Exemplary of Community Leaders as The Model In Building National Character}

The Banuroja community's success in strengthening social integration cannot be separated from the role of community leaders, such as the ethnic figures, youth leaders, and religious leaders. The community leaders provide examples in the form of good attitudes and behavior to their citizens. This exemplary is an example of the behavior of the characters in their daily life. The exemplary is imitation, namely imitating students against educators; the imitation process that children do with adults; the process of imitating children against their parents; and imitating a student towards his teacher of imitating community members towards community leaders. Behavioral consistency is needed because there is a process of imitation (Suhono \& Utama, 2017).

Another form of exemplary can be seen from the mutual respect and appreciation among community leaders. This attitude is shown by attending to each other's religious activities to provide an example for their followers. It is as stated by I Made Suardana that "the people here 
really respect the diversity of every ethnicity, in each religion, have figures that provide the enlightenment or foster tolerance to their respective followers." Likewise, when facing disputes in society, friendship and communication between community leaders effectively resolve these disputes. Besides, KH. Abdul Ghofir Nawawi, as a central figure, has an essential role in protecting and uniting the diversity of the Banuroja community, as stated by Hasanuddin (2015), that "Haji Ghofir Nawawi is a role model and is respected by people of all religions and all ethnicities in Banuroja. He is a moderate Islamic leader who strongly emphasizes that pluralism is a fact of Indonesian socio-cultural life that must be well accepted". His figure is a role model for the residents because he is always prudent and wise in making decisions / or policies related to the dynamics of the village life without distinguishing each person's group's identity. Thus, the example of community leaders has shown an excellent character-building model for the multicultural Banuroja community.

National character is the character or character of a nation that characterizes and can differentiate it from other nations. In Budimansyah (2010) term, the nation's character is "the national personality which is imbued with the values of Pancasila, and norms based on the 1945 Constitution of the Republic of Indonesia". The national character values are the Banuroja community's guidelines in maintaining harmony and intimacy amidst the diversity of society, whether ethnic, religious, or cultural. The value is reflected in the community's character that honors and respects each other, works together, and builds an attitude of mutual understanding. This condition is the driving factor for the achievement of social integration as stated by Soekanto (2011) that there is a sense of tolerance, mutual respect, and tolerance; b) mutual respect for others and their culture; and c) increasing the social solidarity which is influenced by the intensive group cooperation in the society in facing common events.

Community character is a social capital for them in building a safe and peaceful life. There are two categories in the social capital, namely those that emphasize social relationship networks and emphasize the characteristics inherent in individuals who are involved in the social interactions (Ancok, 2003). Habituation is carried out to nourish the community's social capital, namely, the character values themselves. The implementation of national character values is a priority for the Banuroja community because it is in line with the values of local wisdom preserved and developed until now to develop the quality of the community's character. The quality of character can be seen from understanding and people's attitudes which show the value of virtue and civility in responding to the differences. In the concept of the Center for Civic Education, Wahab and Sapriya (2011) stated that the quality of citizenship is referred to as the conception of virtue and civic culture, which includes civic knowledge, civic disposition, and citizenship skills (civic skill).

With mutual and high tolerance in daily interactions, the good character has strengthened the social integration in people with different cultural backgrounds. In Fraser's term (Bessone, 2013) that "toleration can take the form of the 'respect conception,' in which tolerating and tolerated parties recognize each other as political and moral equals, despite their profound cultural and ethical differences." Besides, good character can strengthen the democratic behavior that highly values equality and responsible freedom in social life.

In every activity, the nation's character's value is carried out consistently by the whole community, especially the community leaders who have significant influence and contribution in 
developing a more independent community character. In Budimansyah (2010) terms, building the national character gives citizens a more independent position towards the state, emphasizing improving the moral relations between citizens themselves and cultivating the value of harmony that generates concern for all citizens.

Preserving the national character values is a preventive effort to prevent the Banuroja community from the various social threats. These threats can come from the internal communities, as well as from the external parties. The internal threat is such as fighting among youth over misunderstandings that can lead to social conflict. Meanwhile, the threats from external parties such as provocation from outside the Banuroja community can divide society, such as inviting the residents to be intolerant of other religions by spreading hate speech. However, these various threats have been able to be controlled and overcome because of the community's strong awareness that the various provocations do not easily provoke them. They remain committed to maintaining the integrity of their diverse society.

It sometimes does not happen in other areas. The diversity of society is actually the factor in causing conflicts and even social conflict because there is no mutual respect, respect for differences, and upholding a sense of unity, especially in the ethnic and religious differences. In terms of Antonsich and Matejskova (2015) "Ethno-culture and religion often tend to move beyond the nation-state which is the site of oppression and discrimination." Such a condition is certainly undesirable if it occurs in the Banuroja community. Negative attitudes such as intolerance and sectoral egoism involving ethnicity or religion are avoided in their lives. Therefore, to prevent negative attitudes from appearing in the society, efforts are made to foster the national character values in the society through national and religious activities in the community, learning and habituation activities at school, parental advice to children in the family environment, and exemplary from the community leaders. Thus, the formation of multiculturalism and social integration in the Banuroja multicultural society can be maintained until now.

\section{Conclusion}

Understanding and internalizing the value of multiculturalism into the person of a culturally diverse society is fundamental to guarantee the rights of individuals to defend their culture, as well as a standard of values / ethics for society to prevent division, conflict, and even social conflict so that it must be maintained and respected in a manner together. The things that determine the formation of a multiculturalism society: 1) Habituation in carrying out the values of national character in the community, family, and school; 2) Fostering the national character values through activities in the community, in the family, and at school; 3) Exemplary of community leaders as the model for building national character. The three things are carried out in harmony, suitability, balance, and mutual support. Thus, multiculturalism in the Banuroja multicultural environment is achieved so that social integration is formed, leading to a peaceful and caring life. As for the recommendations for further research, namely considering that this research has only reached the exploration stage regarding the value of multiculturalism and social integration of the life of the Banuroja community, further research is expected to focus on how the influence of the existence of the Banuroja community on the people in the surrounding area, of as they can understand further and intact about the existence of Banuroja community life in the surrounding environment. 


\section{References}

Ancok, D. (2003). Modal sosial dan kualitas masyarakat [Social capital and community quality]. Psikologika: Jurnal Pemikiran dan Penelitian Psikologi, 8(15), 4-14. https://doi.org/10.20885/psikologika.vol8.iss15.art1.

Antonsich, M., \& Matejskova, T. (2015). Immigration societies and the question of 'the national.' Ethnicities, 15(4), 495-508. https://doi.org/10.1177/1468796815577705

Asrori, M. (2019). Pembinaan karakter anak pada masyarakat perumahan di pinggiran kota. Jurnal Civics: Media Kajian Kewarganegaraan, 16(1), 69-79. doi:https://doi.org/10.21831/jc.v16i1.20344

Azra, A. (2007). Identitas dan krisis budaya, membangun multikulturalisme Indonesia [Identity and cultural crisis, build Indonesian multiculturalism]. Pustaka Indonesia.

Bessone, M. (2013). Beyond liberal multicultural toleration: A critical approach to groups' essentialism. European Journal of Political Theory, 12(3), 271-287. https://doi.org/10.1177/1474885112465245.

Budimansyah, D. (2010). Penguatan pendidikan kewarganegaraan untuk membentuk karakter bangsa [Strengthening the civic education to shape the character of the nation]. Widya Aksara Press.

Coleman, S. J. (2008). Dasar-dasar teori sosial [Basics of social theory]. Nusa Media.

Creswell, J. W. (2015). Riset pendidikan: Perencanaan, pelaksanaan, dan evaluasi kualitatif dan kuantitatif [Educational research: Planning, implementing, and qualitative and quantitative evaluation] (5th edition). Pustaka Pelajar Offset.

Ernas, S. (2018). Dari konflik ke integrasi sosial: Pelajaran dari Ambon-Maluku [from conflict to social integration: Lessons from Ambon-Maluku], International Journal of Islamic Thought, 14(Dec), pp. 99-111. https://doi.org/10.24035/ijit.14.2018.009.

Faisal, A. (2019). Banuroja (satu desa tiga agama): Model Kerukunan Sosial di Gorontalo [Banuroja (One Village with Three Religions): A Model of Social Harmony in Gorontalo]. KARSA: Jurnal Sosial dan Budaya Islam, 27 (1), 95-114. DOI: http://dx.doi.org/10.19105/karsa.v27i1.2219

Fajar, W. N., \& Wati, R. K. (2012). Konstruksi Pendidikan Nilai dan Moral Bagi Anak Jalanan dalam Mengembangkan Smart and Good Citizen [Construction of Value and Moral Education for Street Children in Developing Smart and Good Citizen]. Sainteks, 9(2), 9-21. https://doi.org/10.30595/sainteks.v9i2.267.

Fay, B. (1996). Contemporary philosophy of social science: a multicultural approach. Blackwell.

Fromm, E. (2002). The sane society. Routledge Classics.

Hasanuddin, H. (2015). Strategi masyarakat multikultural dalam membina kerukunan sosial di Desa Banuroja Provinsi Gorontalo [multicultural community strategy in fostering the social harmony in Banuroja Village, Gorontalo Province]. Kepel Pres.

Jubba, H. (2019). Kontestasi identitas agama: Lokalitas, siritual di Indonesia [Contestation of Religious Identity: Spiritual Locality in Indonesia]. The Phinisi Press.

K, A. H., \& Mahyuddin, M. (2019). Modal Sosial dan Integrasi Sosial: Asimilasi dan Akulturasi Budaya Masyarakat Multikultural di Polewali Mandar, Sulawesi Barat [Social Capital and Social Integration: Cultural Assimilation and Acculturation of Multicultural Community in 
Polewali Mandar, West Sulawesi]. KURIOSITAS: Media Komunikasi Sosial dan Keagamaan, 12(2), 111-122. https://doi.org/10.35905/kur.v12i2.1104

Kærgård, N. (2010). Social cohesion and the transformation from ethnic to multicultural society: The Case of Denmark. Ethnicities, 10(4), 470-487. https://doi.org/10.1177/1468796810378323.

Kauff, M., Asbrock, F., Thörner, S., \& Wagner, U. (2013). Side effects of multiculturalism: the interaction effect of a multicultural ideology and authoritarianism on prejudice and diversity beliefs. Personality and Social Psychology Bulletin, 39(3), 305-320. https://doi.org/10.1177/0146167212473160

Kowalczyk, J. dan Popkewitz, T. S. (2005). Multiculturalism, Recognition, and Abjection: (re)mapping Italian identity. Policy Futures in Education, 3(4), hlm. 423-435.

Layendecker, L. (1983). Tata perubahan dan ketimpangan: suatu pengantar sejarah sosiologi [System of change and inequality: an introduction to the history of sociology]. Gramedia.

Mangunsong, N., \& Fitria, V. (2019). Pancasila dan toleransi pada tradisi keagamaan masyarakat Yogyakarta [Pancasila and tolerance to the religious traditions of Yogyakarta People]. Jurnal Civics: Media Kajian, 16(1), 89-97. https://doi.org/10.21831/jc.v16i1.25312.

Morgenthau, H. (1963). Politics among nations: The struggle for power and peace. (third edition). Alfred A. Knopf.

Muhammad, N. (2015). Pergerseran nilai-nilai religius: Tantangan dan harapan dalam perubahan sosial [a shift in religious values: challenge and expectation in the social change]. SUBSTANTIA: Jurnal Ilmu-IImu Ushuluddin, 17(2), 191-202.

Nathan, G. (2015). A non-essentialist model of culture: Implications of identity, agency, and structure within multinational/multicultural organizations. International Journal of Cross Cultural Management, 15(1), 101-124. https://doi.org/10.1177/1470595815572171.

Noe, W., Affandi, I., Malihah, E., \& Sunatra, S. (2018). The dynamics of multicultural values of Banuroja community in building social integration a socio-cultural ethnographic study in Gorontalo. Journal of Human Behavior in the Social Environment, 28(6), 758-770. https://doi.org/10.1080/10911359.2018.1458680.

Purna, I. M. (2016). Kearifan lokal masyarakat desa Mbawa dalam mewujudkan toleransi beragama [The local wisdom of the people of Mbawa village in realizing the religious tolerance]. Jurnal Pendidikan dan Kebudayaan 1(2), 261-277. https://doi.org/10.24832/jpnk.v1i2.764.

Rifai, A. (2017). Perpustakaan dan pendidikan multikulturalisme [library and multiculturalism education]. Media Pustakawan, 14(2), 62-68.

Soekanto, S. (2011). Mengenal tujuh tokoh sosiologi [Recognize the seven figures of sociology]. Rajawali Press.

Suhono, \& Utama, F. (2017). Keteladanan orang tua dan guru dalam pertumbuhan dan perkembangan anak usia dini [exemplary parents and teachers in the early childhood growth and development] (perspective of abdullah nashih ulwan kajian kitab tarbiyyah al-aulad fi alislam). Elementary, 3(2), 107-119. https://doi.org/10.32332/elementary.v3i2.833.

Sumaatmadja, N. (2005). Pendidikan Pemanusiaan Manusia Manusiawi [Humane Human Humanity Education]. Alfabeta. 
Suparlan, P. (2002). Menuju masyarakat Indonesia yang multicultural [Lead to a multicultural Indonesian society]. Antropologi Indonesia, 69(1), 98-105. https://doi/org/10.7454/ai.v0i69.3448.

Sutiyono. (2011). Benturan budaya Islam: Puritan dan sinkretis [The clash of Islamic cultures: Puritan and syncretic]. Kompas.

Syafar, D. (2019). Pluralisme agama dalam pendidikan (potret toleransi beda agama di SD Negeri 46 Hulontalangi kota Gorontalo) ['religious pluralism in education (portrait of tolerance for different religions in SD Negeri 46 Hulontalangi city of Gorontalo)], Jurnal Kajian Islam, 2(2). 99-115.

Verkuyten, M., \& Yildiz, A. A. (2007). National (dis)identification and ethnic and religious identity: a study among turkish-dutch muslims. Personality and Social Psychology Bulletin, 33(10), 1448-1462. https://doi.org/10.1177/0146167207304276.

Wahab, A. A. Sapriya. (2011). Teori dan landasan pendidikan kewarganegaraan [Theory and foundation of citizenship education]. Alfabeta.

Walidaeni, B. (2018). Peran pesantren Subulussalam dalam membangun keharmonisan masyarakat pluralistik di desa Widodaren Petarukan Pemalang [The role of the Subulussalam islamic boarding school in building the harmony in a pluralistic society in Widodaren Petarukan Pemalang Village] (Doctoral dissertation, UIN Walisongo).

Wardhani, N. W., \& Narimo, S. (2018). Strength of the tolerance in the country through the tepaslira directed to the community Java in Surakarta. In Annual Civic Education Conference (ACEC 2018) Atlantis Press, 392-394. https://doi.org/10.2991/acec-18.2018.89.

Wardhani, N. W., Arumsari, N., \& Wijayanti, T. (2019). Pemahaman pentingnya kesadaran akan pendidikan karakter anak melalui sinergi lingkungan pendidikan di Kecamatan Gunungpati [understanding the importance of awareness of children's character education through the synergy of the educational environment in gunungpati district]. JURNAL PANJAR: Pengabdian Bidang Pembelajaran. 1(2), 107-110.

Wardhani, N.W. (2020). Pendidikan moral (urgensi dan implementasi) [moral education (urgency and implementation)]. Raja Grafindo.

Watson, C.W. (2000). Multiculturalism. Open University Press.

Whittaker, G. R. (2014). Developing a plural nation? Black and minority ethnic participation in the 2011 Welsh referendum. Ethnicities, 15(3), 385-413.

Wolsko, C., Park, B., Judd, C. M., \& Wittenbrink, B. (2000). Framing interethnic ideology: Effects of multicultural and color-blind perspectives on judgments of groups and individuals. Journal of Personality and Social Psychology, 78(4), 635-654. https://doi.org/10.1037/00223514.78.4.635

Yousuf, Z. (2007). Unravelling identities: Citizenship and legitimacy in a multicultural Britain. European Journal of Cultural Studies, 10(3), 360-373. https://doi.org/10.1177/1367549407079709

Zaenuri, A., \& Pratama, I. P. (2019). Basis pluralis-multikultural di pesantren. [Pluralist-multicultural basis in boarding school]. Conciencia, 19(2), 70-84. https://doi.org/10.19109/conciencia.v19i2.4284. 